\title{
Emotional Intelligence among Native and Migrant Adolescents at Sultanpur District: A Comparative Study
}

\author{
Pinka Patel ${ }^{1}$, U.V. Kiran ${ }^{2 *}$ and Kumari Santoshi ${ }^{3}$ \\ 'MSc. Student, Human Development and Family Studies, School for Home Sciences, Babasaheb Bhimrao Ambedkar \\ University, Lucknow - 226025, Uttar Pradesh, India; pinka.anu95@gmail.com \\ 2 Professor, Human Development and Family Studies, School for Home Sciences, Babasaheb Bhimrao Ambedkar \\ University, Lucknow - 226025, Uttar Pradesh, India; druvkiran@gmail.com \\ ${ }^{3}$ Research Scholar, Human Development and Family Studies, School for Home Sciences, Babasaheb Bhimrao \\ Ambedkar University, Lucknow - 226025, Uttar Pradesh, India; tosibhu@gmail.com
}

\begin{abstract}
Background: Adolescence is the transitional phase of growth and development from childhood to adulthood. It is the period of critical development of physical and mental changes that takes place quickly with emotional changes among them. Emotional intelligence is the ability to perceive, understand, use, and manage your own emotions as well as those of the others around you in positive way. Aim: The aim of this study was to identify the emotional intelligence among normal and migrant adolescents. Materials and Methods: The study was conducted on120 adolescents, selected randomly in different areas of Sultanpur District. The general information sheet and the Emotional Intelligence Scale developed by Hyde et al (2001) were used for data collection. Results: The study clearly revealed that native and migrant adolescents exhibited differences in understanding emotions, motivation, empathy and handling relations. Conclusion: Emotional intelligence of a child has a prominent and very potent role in overall personality development. Understanding one's own emotions as well the others is influenced by many prominent factors like the living environment, family support system, the school, the peer group etc. Migrants move from one place to other place for their livelihood, they don't have standard pattern of life style and support, children of these families, hence get influenced by many external stimuli and to avoid influence of negative stimuli, counselling sessions may be of great help.
\end{abstract}

Keywords: Emotional Intelligence, Native Adolescents, Migrant children, Native children

\section{Introduction}

Adolescence is the age when a person acquires the ability to think further than the present, envision its implications and the future to develop a strong relationship in society. They will have to deal with the new experiences and an unknown situation often leads to new, and may have intense, positive, and negative emotional reactions. There is a need to foster the emotional intelligence skills for regulating their emotions and behaviour. They compelled to move to escape extreme poverty, lack of access to land, food, water, decent work, education, and healthcare. In transit, migrant adolescents are at risk of violence, including kidnapping, abduction and extortion, trafficking, sexual exploitation, economic exploitation, child labour, begging, or the involvement in criminal and illegal activities ${ }^{1}$.

Peter Salovey and John Mayer coined the term emotional intelligence in 1990. They defined the emotional intelligence
(EI) as the ability to observe one's own as well as others' feelings and emotions, to discriminate among them, and to use this knowledge to direct one's thinking and actions ${ }^{2}$. Later they came up with the definition as "The ability to perceive emotion, integrate emotion to facilitate thought, understand emotions, and to regulate emotions to promote personal growth"3. Emotional intelligence refers to a combination of skills these including empathy, self-control, self-awareness, sensitivity to the feeling of others, persistence and self-motivation among others ${ }^{4}$. Emotional intelligence of adolescents is not impacted whether adolescents are normal or differently abled person ${ }^{5}$. Children who live with their parents and family possess higher emotional intelligence in comparison to street children who live alone and in these cases girls has more emotional intelligence than the boys ${ }^{6}$.

Social integration and the health of adolescents with a migration background is a major concern in multicultural societies ${ }^{7}$. Comparing native and migrant children and

*Author for correspondence 
adolescents, the Asian migrant group was at higher risk of developing mental disorders. Family-based risk factors were offered: high acculturation stress, low English language competence, language brokering, discrepancies in children's and parent's cultural orientation, the non-Western cultural orientation ${ }^{8}$. The resilient processes through which perceived emotional intelligence affects student's life satisfaction were similar for males and females 9 . The present study was carried out to assess the emotional intelligence among native and migrant adolescents.

\section{Materials and Methods}

\subsection{Sample}

Sample was selected from different areas of Sultanpur District to carry out this research. The sample included a group of native and migrant and they were selected using random sample technique. Multistage random sampling technique was used to select native children. Four schools were narrow down from selected areas. The information of students from the schools were obtained, taken the consent and the Google forms were forwarded to all the students, totalling to 120 comprising of both the genders. Responses were obtained from 90 students and after sorting, 79 were found accurate and the same were analysed.

\subsection{Tools Used}

To carry out the present study general information sheet and the Emotional Intelligence Scale developed by Hyde et al. (2001) were used.

Emotional Intelligence Scale (EIS) measures included following four dimensions -

1. Understanding Emotions: An individual's ability to recognise one's own and other's physical states, feelings, and thoughts.

2. Understanding motivation: The driving force behind human actions together with the tendency to be optimistic and take new initiative.

3. Empathy: Ability to understand how other people feel.

4. Handling emotions: To be able to manage emotions in a better way.

On the basis of these dimensions EIS qualitatively interpreted in emotional levels as shown in table 1.

Table 1. Qualitative interpretation of Emotional Intelligence scale

\begin{tabular}{|c|c|}
\hline Range or Score & Interpretation \\
\hline 20 or less & Low Emotional Intelligence \\
\hline 21 to 26 & Average Emotional Intelligence \\
\hline 27 and above & High Emotional Intelligence \\
\hline
\end{tabular}

\subsection{Data Collection}

The general information sheet and the Emotional Intelligence Scale developed by Hyde et al. $(2001)^{10}$ were converted into Google Forms and the same were used to collect information from native children.

Interview method was used to collect information from the migrant adolescents using the same tools. Migrant children are selected using purposive sample technique from the identified areas in Sultanpur District. A total of 41 adolescents have agreed to respond and the same were selected as sample under migrant children. While collecting the data government guidelines of COVID-19 were followed without affecting in any loss of information of respondents. The sample was identified and permission was sought from his parents or legal guardians to collect the data as respondents are adolescents. Efforts were made to maintain the accuracy and relevance of the answers.

\subsection{Statistical Analysis}

The data was coded and analysed using IBM SPSS 20.0 Version. The data were expressed as the mean and standard deviation, to measure the relationship among emotional intelligence and residential status, independent $\mathrm{t}$-test was used. Through correlation statistics, the relationship among the variables was assessed. In addition, specific linear bivariate correlation testing to determine the relationship of emotional intelligence and residential status was obtained. The demographic profile was assessed using frequency and percentage.

\section{Results and Discussion}

\subsection{Demographic Profile of the Respondents}

Table 2 describes the residential status of the respondents. Native respondents were $65.8 \%$ and migrants were $34.2 \%$ of the total identified samples.

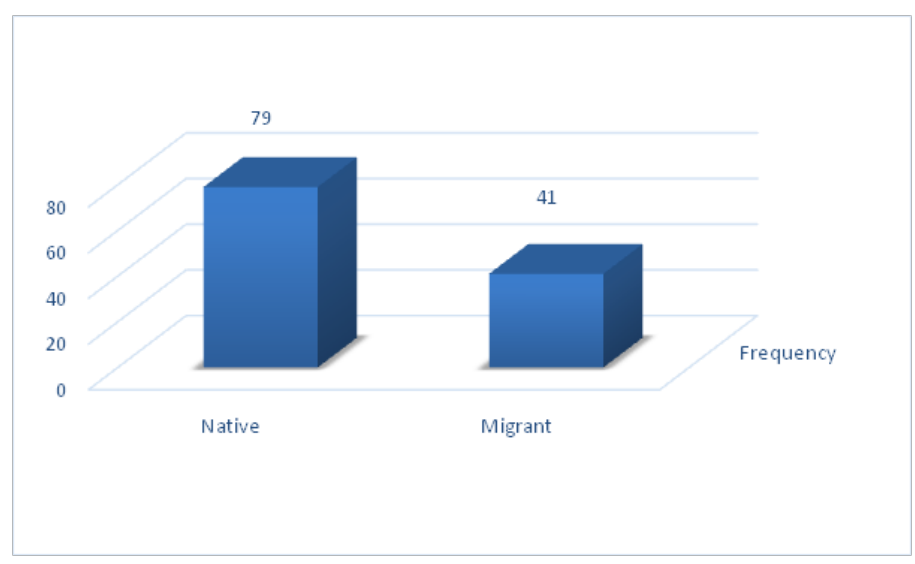

Figure 1. Distribution of respondents on the basis of their age. 
Table 2. Distribution of respondents according to the Residential Status

\begin{tabular}{|l|c|c|}
\hline S. No. & Residential status & Frequency (\%) \\
\hline 1 & Native & $79(65.8)$ \\
\hline 2 & Migrant & $41(34.2)$ \\
\hline
\end{tabular}

(Figures in parenthesis indicates percentage)

Table 3 shows the crosstab distribution between gender and the residential status. Of the total migrant respondents $48.8 \%$ were boys and $51.2 \%$ were girls, similarly amongnative respondents $81 \%$ were boysand $19 \%$ were girls.

Table 3. Distribution of gender according to residential status

\begin{tabular}{|c|c|c|c|}
\hline \multirow{2}{*}{ S. No. } & \multirow{2}{*}{$\begin{array}{c}\text { Residential } \\
\text { status }\end{array}$} & \multicolumn{2}{|c|}{ Gender of respondents } \\
\cline { 3 - 4 } & Native & $64(81.0)$ & Girls \\
\hline 1 & Migrant & $20(48.8)$ & $15(19.0)$ \\
\hline 2 & & $21(51.2)$ \\
\hline
\end{tabular}

(Figures in parenthesis indicates percentage)

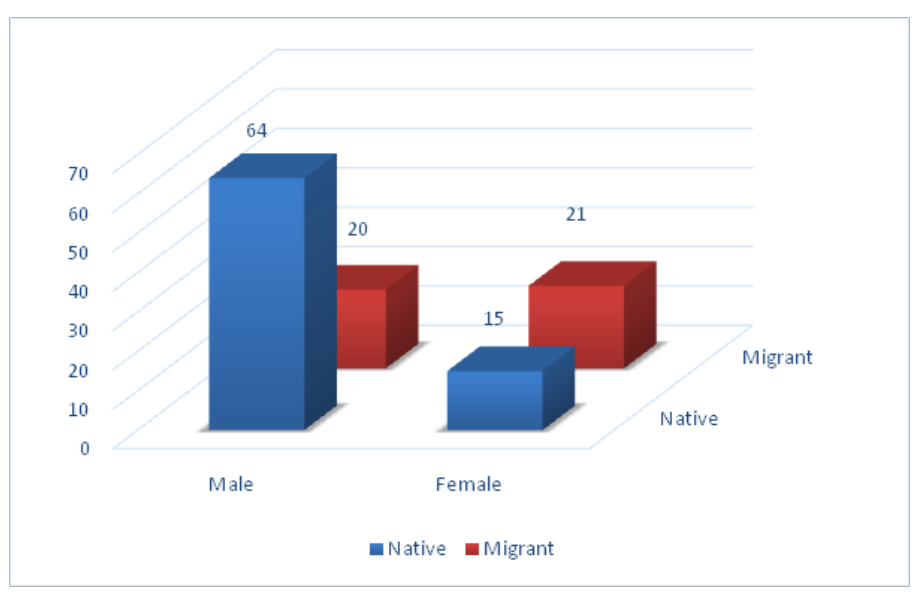

Figure 2. Distribution of gender according to residential status

Table 4. Emotional Intelligence according to Residential Status

\begin{tabular}{|c|c|c|c|c|c|c|c|}
\hline \multirow{2}{*}{ S. } & \multirow{2}{*}{$\begin{array}{c}\text { Emotional } \\
\text { No. }\end{array}$} & \multicolumn{3}{|c|}{ Residential Status } & \multirow{2}{*}{ Intigence } & \multirow{2}{*}{$\mathbf{P}$} \\
\cline { 3 - 6 } & & \multicolumn{2}{|c|}{ Native } & \multicolumn{2}{|c|}{ Migrant } & T & \\
\cline { 3 - 6 } 1 & $\begin{array}{c}\text { Understanding } \\
\text { emotions }\end{array}$ & 1.40 & 1.03 & 1.17 & 1.13 & 1.10 & 0.27 \\
\hline 2 & $\begin{array}{c}\text { Understanding } \\
\text { motivation }\end{array}$ & 3.22 & 1.56 & 2.58 & 1.22 & $2.47^{* *}$ & 0.01 \\
\hline 3 & Empathy & 3.68 & 1.91 & 3.04 & 1.54 & $1.95^{*}$ & 0.05 \\
\hline 4 & $\begin{array}{c}\text { Handling } \\
\text { relations }\end{array}$ & 3.02 & 1.78 & 2.21 & 2.13 & $2.06^{*}$ & 0.04 \\
\hline 5 & $\begin{array}{c}\text { Emotional } \\
\text { Intelligence } \\
\text { Total }\end{array}$ & 11.34 & 4.61 & 9.02 & 4.87 & $2.51^{* *}$ & 0.01 \\
\hline
\end{tabular}

$(\mathrm{M}=$ Mean, S.D. $=$ Standard Deviation $),{ }^{*}$ Significant $\mathrm{P}<0.05,{ }^{*}$ highly significant $\mathrm{P}<0.01$
The emotional intelligence of native and migrant adolescents was assessed under three levels - High, Moderate and Low and the data of the same is presented in table 4. It is evident from the data that emotional understanding was higher $(\mu=1.40)$ among native adolescents in comparison to migrant adolescents, since they live along with their families and share their emotions with them. Motivational understanding is also found to be more in native adolescents $(\mu=3.22)$ than in migrants. Native adolescents are motivated by their family members (like parents and grandparents) indicating that family support plays a prominent role. Native adolescents handle relations in a better way $(\mu=3.02)$ than the migrants. Significant differences were found in empathy of native adolescents $(\mu=3.68)$ and migrant adolescents indicating that native adolescents are more empathetic and they relate and cooperate with others substantially. Significant differences were also found in understanding motivation and handling relations. The results are projection ofclear evidence that family, parents and peer groups pose a very important role in shaping the life of adolescents.

Table 5. Association between Emotional Intelligence and Residential Status

\begin{tabular}{|c|c|}
\hline $\begin{array}{c}\text { Residential } \\
\text { Status }\end{array}$ & Emotional Intelligence \\
\cline { 2 - 2 } & $0.23^{\star *}$ \\
\hline
\end{tabular}

${ }^{\star} \mathrm{S}=$ Significant $(\mathrm{P}<0.01)$

The correlation between the residential status of native and migrant adolescents and their emotional intelligence is shown in table 5. It can be noted from the above table thatthere is a strong relationship between the emotional intelligence and residential status among native and migrant adolescents. The correlation value $(r=-0.23)$ depicts the strength and direction of relationship between them which was statistically significant indicating that the emotional intelligence was high among native adolescents in comparison to migrant adolescents.

Table 6. Association between level of Emotional Intelligence and Residential Status

\begin{tabular}{|c|c|c|c|c|c|c|}
\hline S. & Residential & \multicolumn{2}{|c|}{ Emotional Intelligence } & \multirow{2}{*}{ Chi } & Cramer's \\
\cline { 3 - 5 } No. & Status & Low & Average & High & & V \\
\hline 1 & Native & 39.2 & 58.2 & 2.5 & & \\
\hline 2 & Migrant & 63.4 & 36.6 & 0.0 & & $0.83^{*}$ \\
\hline
\end{tabular}

The data in table 6 portrays the association between residential status of native and migrant adolescents and their emotional Intelligence levels.Significant differences were found in the emotional intelligence among native and migrant adolescents with a chi square value of 6.84. It is evident from the data that majority $(63.4 \%)$ of migrant adolescents have lowest emotional intelligence in comparison to only 39.2 
percent of native adolescents which was followed by moderate intelligence scores of 58.2 and 36.6 percent of native and migrant adolescents, respectively. It can also be seen from the data that 2.5 percent of native adolescents have high emotional intelligence whereas none of the migrant respondents were have high emotional intelligence.

\section{Conclusion}

Emotional intelligence plays a crucial role for social adjustment which will help the adolescents to cope with environmental demands and pressure. The present research once again reiterated the importance of family in framing the personality of any human being. Emotional intelligence influences the relationships and behaviour in society. Native adolescents exhibited higher emotional intelligence than the migrants due to the enormous influence of family which motivates and supports them in all aspects of life for their development. Children who live with families also learn handling relations in better way but migrant adolescents are left behind in emotional intelligence due to lack of family, parents and close one's support and being away from native place. Family environment and the place where they live are important factors to regulate and integrate emotional intelligence. Migrants move from one place to other place for their livelihood, they don't have standard pattern of life style and support, children of these families, hence get influenced by many external stimuli and to avoid influence of negative stimuli, counselling sessions may be of great help. NGOs and the local governance also has to work together to train and motivate the adolescents to channelize their energies in positive manner and encourage them to be an asset to the society.

\section{Conflict of Interest}

All the authors declare that there is no conflict of interest.

\section{Acknowledgment}

Authors acknowledge all the respondents who participated in this study. Authors also acknowledge and are grateful for the immense help received from the scholars' whose articles are cited and included in references of this manuscript.

\section{Source of Funding}

The authors received no specific funding for this work.

\section{References}

1. Gilmore, K. (2018). Migration and adolescent health. Journal of Adolescent Health, 63(1), 12-15. https://doi.org/10.1016/j.jadohealth.2018.05.009

2. Salovey, P., \& Mayer, J. D. (1990). Emotional intelligence. Imagination, Cognition and Personality, 9(3), 185-211. https:// doi.org/10.2190/dugg-p24e-52wk-6cdg

3. Mayer, J. D., \& Salovey, P. (1997). What is emotional intelligence? In P. Salovey\& D. Sluyter (Eds.), Emotional development and emotional intelligence: Implications for educators (pp. 3-31). New York, NY: Basic Books

4. Karibeeran, S. (2019). Emotional intelligence among adolescents. Humanities and Social Sciences, 7(3), 121. https://doi. org/10.11648/j.hss.20190703.15

5. Rajbhar, R. \& Kiran, U. V. A study on differences in emotional intelligence among normal and differently abled adolescents. International Journal of Research. 2017; 05(12): 217-221. https:// edupediapublications.org/journals/index.php/IJR/

6. Tripathi, K. \& Kiran, U. V. A study on self-esteem and emotional intelligence among street children. Indian Journal of Applied Research. 2018; 8(11). https://doi.org/10.36106/ijar

7. Lorant, V., Victoria, S. R., Bécares, L., Kinnunen, J. M., Kuipers, M. A., Moor, I., Roscillo, G., Alves, J., Grard, A., Rimpelä, A., Federico, B., Richter, M., Perelman, J., \&Kunst, A. E. A social network analysis of substance use among immigrant adolescents in six European cities. Social Science \& Medicine. 2016; 169:58-65. https://doi.org/10.1016/j.socscimed.2016.09.031

8. Kouider, B.E., E., Koglin, U., \&Petermann, F. Emotional and behavioral problems in migrant children and adolescents in American countries: A systematic review. Journal of Immigrant and Minority Health. 2014; 17(4): 1240-1258. https://doi. org/10.1007/s10903-014-0039-2

9. Ramos-Díaz, E., Rodríguez-Fernández, A., Axpe, I., \& Ferrara, M. (2019). Perceived emotional intelligence and life satisfaction among adolescent students: The mediating role of resilience. Journal of Happiness Studies: An Interdisciplinary Forum on Subjective Well-Being, 20(8), 2489-2506. https://doi.org/10.1007/ s10902-018-0058-0

10. Hyde, A., Pethe, S., \& Dhar, U. (2001).Manual for emotional intelligence scale.Agra: National Psychological Corporation. 